\title{
The sociology of a pandemic Countering a COVID 'disinfodemic' with a campus media initiative
}

\begin{abstract}
Parallel with the global spread of the novel coronavirus pandemic, a dangerous 'disinfodemic' has been infecting the flow of information worldwide. Communication and media outlets have faced a new challenge with not only being responsible for reportage and analysis of a fast-moving public health emergency - the biggest this century, but forced to sift through the mass circulation of falsehoods that have spread as rapidly as the virus. Concerned about the risks for both health and public responses to disinformation, United Nations Secretary-General António Guterres identified the 'new enemy' as a 'growing surge of disinformation'. The UN launched a COVID-19 Communications for Solidarity Initiative to rapidly inform people about facts and science and to 'promote and inspire acts of humanity' globally. Also alarmed by the growing disinformation trend, the World Health Organisation warned that the 'same enemy' also involved 'an increase in stigma, hate speech and hate crimes' over the pandemic. Aotearoa New Zealand is one of the few countries in the world whose strategy of COVID elimination has been a sustained approach to 'keep the virus out, find it and stamp it out'. Evoking a theme of 'our team of five million' and national kindness, Prime Minister Jacinda Ardern has led a remarkable campaign blending decisive action and transparency. As at October 25, the country has had only 22 deaths from the first wave of the pandemic and with a second wave cluster in August three further deaths and a combined total of 1935 cases with 260 having been contained in quarantine or managed isolation at the border. In this context, this article critically examines a four-month 'Coronavirus Plus' initiative conducted by the Pacific Media Centre at a communication programme in one of the New Zealand's universities in response to the pandemic, deploying the Asia Pacific Report website, asiapacificreport.nz.
\end{abstract}

Keywords: case studies, coronavirus, COVID-19, disinformation, Frontline, health journalism, journalism as research, journalism education, New Zealand, pandemic, truth-telling

\section{DAVID ROBIE with SRI KRISHNAMURTHI}

\section{Pacific Media Centre, Auckland University of Technology}

WO WEEKS into Aotearoa/New Zealand's COVID-19 coronavirus pandemic lockdown in April 2020, the United Nations Educational, Scientific and Cultural Organisation (UNESCO) warned that false information 
campaigns about the coronavirus pandemic were a 'grave danger' to many people's lives around the world (UNESCO, 2020). This followed a warning in mid-February by the World Health Organisation (WHO) Secretary-General, Dr Tedros Adhanom Ghebreyesus, who declared at a gathering of foreign policy and security experts in Munich, Germany, that 'we're not just fighting an epidemic; we're fighting an infodemic'. He added that the fake news 'spreads faster and more easily than this virus' (UN tackles 'infodemic', 2020). Concerned about the risks for both health and public responses to disinformation, UN Secretary-General António Guterres identified the 'new enemy' as a 'growing surge of disinformation'. The UN launched a COVID-19 Communications for Solidarity Initiative through 'digital first responders' to rapidly inform people about facts and science and to 'promote and inspire acts of humanity' globally (UN launches new initiative, 2020).

The term 'disinfodemic' was adopted by the authors of a policy brief (Posetti \& Bontcheva, 2020) for UNESCO to describe the 'falsehoods fuelling the pandemic' and its impacts because of the 'huge viral load of potentially deadly disinformation' that had been described by Guterres as 'a poison' and humanity's other 'enemy' in this crisis.

\section{Background and context}

Hoax stories and conspiracy theories have proliferated online and have continued to do so. The 'disinfodemic' has led people infected by the virus to try unproven treatments and false cures that were dangerous, according to UNESCO. An example of this risky disinformation came from US President Donald Trump (one of many that he peddled before losing a tightly fought election on November 3) - he was lambasted by the medical fraternity after suggesting research into whether the coronavirus might be treated by injecting disinfectant into the body (Coronavirus: Outcry, 2020). Disinfectants are hazardous substances. Trump also appeared to propose irradiating patients' bodies with UV light, a notion rejected by a doctor at the media briefing. Guy Berger, UNESCO's director for freedom of expression and media development, told the UN's self-reporting news agency:

There seems to be barely an area left untouched by disinformation in relation to the COVID-19 crisis, ranging from the origin of the coronavirus through to unproven prevention and 'cures' and encompassing responses by governments, companies, celebrities and others. (During this coronavirus pandemic, 2020)

From a human rights perspective, and this is one that influences the Pacific Media Centre and its projects such as the 'Coronavirus Plus' coverage cluster, critically important is the notion that it is 'everybody's right to seek, receive and impart information' (Universal Declaration of Human Rights: Article 19, 
1948). And that this information is truthful and trustworthy. UNESCO and its partners work to protect and strengthen this right and build 'knowledge societies' in a range of ways, including:

- Countering the contamination of disinformation,

- Supporting independent, quality journalism,

- Empowering global citizens with media and information literacy, and

- Assisting member states in meeting international standards on freedom of expression.

According to a UNESCO policy brief, four lines of action are essential for the right to health, which is one of the economic, social and cultural rights recognised by the international community (Posetti \& Bontcheva, 2020). They are all essential if humanity is to achieve the UN Sustainable Development Goal (SDG) 16.10 on 'public access to information and fundamental freedoms'. This SDG target helps power other SDGs, especially SDG 3 on 'good health and wellbeing' which is so critical in these times.

The policy brief offers two typologies for understanding the disinfodemic: Firstly, it identifies nine key themes and four main format types associated with disinformation about COVID-19 and its impacts. The themes range from false information about the origins, spread, infection and mortality rates, through to symptoms and treatments, and include content designed to defraud, along with political attacks on journalists and misrepresentation of credible independent journalism as 'fake news' (Posetti \& Bontcheva, 2020). The formats used to disseminate pandemic-related disinformation include: highly emotive narrative constructs and memes; fabricated, fraudulently altered, or decontextualised images and videos; bogus websites, data sets and sources; and disinformation infiltrators and orchestrated campaigns.

The second typology, according to Posetti \& Bontcheva (2020), outlines 10 types of responses to the disinfodemic, which are grouped under four umbrella categories:

- Monitoring, fact-checking, and investigative responses aimed at identifying, debunking, and exposing COVID-19 disinformation;

- governance-based responses, which include law and policy, and statebased counter-disinfodemic responses;

- Curation, technological, and economic responses, which pertain to the policies and practices of institutions mediating content;

- Normative and ethical; educational; empowerment and credibility labelling responses - all of which are aimed at the audiences targeted by disinformation agents, with citizens and journalists being a particular focus.

The purpose of this article is to provide a framework and analysis of the context, rationale and pedagogy of a project initiated by the Pacific Media Centre 
at Auckland University of Technology to cover the pandemic and its impact in New Zealand and Pacific microstates between the date when Prime Minister Jacinda Ardern declared a national lockdown, on 25 March 2020, and when it was finally lifted on June 8 after phasing through four levels of restrictions. While the microstates sought to keep the coronavirus out of their vulnerable countries, a cornerstone of the Ardern government policy was to prevent New Zealand 'inadvertently being the source of an outbreak in the Pacific' (Hopgood, 2020). Early in May, The Lancet declared that New Zealand's 'aggressive' approach had 'eliminated' COVID-19 (Cousins, 2020). That statement proved too premature.

\section{The pandemic and New Zealand's response}

After going for 102 days without recording any case of COVID-19 community transmission, New Zealand became locked for a second time in a campaign to methodically stamp out the coronavirus in what has been branded by some as COVID 'Lockdown 2.0' (Johnson, 2020b). An impending general election was postponed by a month from September 19 to October 17 because of a sudden outbreak involving a Pasifika 'index' family of four people with an unresolved source, not necessarily a border breach. The country anxiously awaited the outcome of this unexpected single cluster that had grown to 149 people after a period of complacency had set in after the earlier success at containing (and apparently eliminating) the virus.

As of September 1, the country had a total number of 1757 confirmed and probable cases of COVID-19, 149 from the community outbreak, and 35 imported cases from managed isolation (MIQ) facilities, with seven people in hospital. There were three further deaths, taking the total to 25. (By October 25 , the infections total overall had climbed slightly to 1935 and nobody was in hospital). While the leadership of Prime Minister Jacinda Ardern has been praised internationally for having one of the finest records in coping with COVID, she has also enjoyed the most popularity of any New Zealand prime minister due to her qualities of effective communication, trustworthiness and empathy. These qualities and the disarray of the opposition National with three leaders in less than three months swept the Labour party to outright victory in the election, an unprecedented result since New Zealand adopted a Mixed Member (MMP) proportional election system in 1996 (Banbury, 2020). As Martyn Bradbury put it, writing for The Daily Blog, if the average New Zealand voter was asked to name one Labour Party policy, they would probably reply: 'Jacinda saved New Zealand'. (Bradbury, 2020).

While many of the international plaudits have been enthusiastic and generous about Ardern's handling of the COVID crisis - ranging from 'master class' (New York Times), to 'squashing the curve' and a decisive 'voice of reason' (TV 
presenter Whoopi Goldberg) - several analysts and commentators have been less kind about New Zealand's news media, one describing their 'machinations' as 'leav[ing] much to be desired' (Forrester, 2020). According to Al Jazeera English contributor Glen Johnson (2020a):

Taken over time, New Zealand's reporters have appeared focused on managing perceptions, berating and cajoling a fearful public on numerous fronts. In doing so, and from the earliest stages of a four-level alert system, public health concerns have been eclipsed by a clamouring commentariat, all seeking to score political points and undermine the government's health-first priorities.

A case can be made that the nation's media, laundering many of the opposition's attack lines and big business talking points, have repeatedly endangered public health.

With multiple clusters across the country in April - a high school in Auckland, a wedding in the deep south, a bar in the tourist hub of Matamata - the government heeded the advice of leading epidemiologists. The Ardern-led government, a coalition at that time of Labour, New Zealand First and the Greens, opted for an elimination strategy. This meant a sustained approach to 'keep COVID-19 out of the country-find it and stamp it out' (COVID-19: Elimination strategy, 2020). This was done by controlling entry at the border; disease surveillance; physical distancing and hygiene measures; testing for and tracing all potential cases; isolating them and their close contacts; and broader public health controls, depending on the alert level.

\section{Internews: Information saves lives}

Internews is a news and current affairs network of more than 750 active partners - including the Pacific Media Centre - 'across five regions, in more than 120 countries, for nearly 40 years in more than 100 languages' (Internews' Strategic Approach, 2020). It launched a five-year strategy in February 2020 just a few weeks before the COVID-19 pandemic "profoundly altered the entire world'. The strategy document was updated in April and has since become more relevant than ever, argues the agency.

COVID has amplified and escalated all of the challenges that we face in our mission to build healthy information environments around the world. The solutions and strengths we bring to this work are as needed as ever. The COVID-19 pandemic is rapidly transforming the information and media systems of every society it touches. The WHO situation report (WHO Situation Report 13, 2020) described the 'infodemic' surrounding the outbreak as 'an over-abundance of information - some accurate and some not - that makes it hard for people to find trustworthy sources and reliable guidance when they need it'. (Internews, 2020, p. 1) 
The Internews COVID-19 response is 'rooted in the knowledge that information can literally save lives'. The agency argues that journalists, civil society leaders and other communicators have been working hard to serve as essential intermediaries between governments, public health experts and the public to help 'stem the infodemic'. Nevertheless, the agency deplores the fact that many governments are 'making this difficult, misleading the public, detaining and arresting those who seek to hold power to account, concealing information, and using the crisis as a justification to suspend human rights, elections, and checks on their power' (Internews, 2020, p. 2). This critique has been shared by a number of media freedom watchdogs, advocates and journalists who have warned against a 'creeping authoritarianism' (Cooper, 2020; Nolan, 2020; Robie, 2020a; RSF, 2020a, 2020b).

According to Internews, the 'biggest story in the world is devastating the news media, as collapsing economies are causing a collapse in the news business, just when we need it the most' (Internews, 2020, p. 3). The Internews approach, as adopted by the Pacific Media Centre in parallel with its Talanoa journalism model (Robie, 2019; Robie \& Marbrook, 2020) in its Pacific COVID and environmental journalism involves five core elements: 1 . Good, accurate, evidence-based information; 2 . That everyone can access safely; 3 . That consumers know how to critically assess; 4 . that is valued by communities and sustained by business models that work; and 5. Where governments and businesses are accountable for keeping it that way (Internews, 2020, pp. 2-3). These are the challenges as outlined by Internews:

People need clear, evidence-based information they can understand and act upon to stay safe. Too often, governments and public health officials give conflicting, confusing, or incomplete guidance. People want to know if it is safe to go to work, if they can send their children to school, where food supplies are available and what to do if they're showing symptoms. People need 'News You Can Use'-news from local sources in their own languages (including Pacific languages) to help understand what this epidemic means for them, their families and their immediate communities.

Misinformation and disinformation are flooding all information environments. The spread of COVID-19 and the risks it poses to communities is compounded by the lack of accurate and up-to-date information amid a proliferation of rumours, myths and misinformation that exacerbate fear, panic, stigma, and mistrust, contributing to further mistrust of the health system and health workers, to mistrust of all information surrounding the outbreak, and to mistrust of preventative behaviours that can save lives. There is evidence that malign actors are purposefully sowing disinformation. People's distrust in corrupt or unaccountable governments helps misinformation and rumours to spread wildly.

Authoritarians exploit fear to silence dissent and accountability: There has been a dramatic increase in crackdowns against freedom of expression in the face 
of COVID-19, often under the guise of combatting misinformation and rumours. Civic space has been rapidly closing around the world and the online space in particular is under assault, with governments censoring information online; rapidly expanding surveillance technologies and policies under the guise of contact-tracing; and exploiting confusion to achieve geopolitical gains. Multiple actors, from governments to hospitals and civil society organisations, are falling victim to digital attacks such as malware, ransomware, and phishing attacks.

Monitoring of these developments can be achieved through some COVID-19 trackers: International Center for not-for-profit Law (ICNL) (https://www.icnl. org/covid19tracker/), Privacy International (https://privacyinternational.org/ examples/tracking-global-response-covid-19), and Reporters Without Borders \#Tracker_19 (https://rsf.org/en/tracker19-Coronavirus-Covid19).

Activists face compounded security risks: While repressive regimes have been increasingly cracking down on information providers over the past decade, COVID-19 is adding to these risks. Journalists work in an environment of fear as they cover COVID-19 without adequate safety protection gear and in the midst of intimidation from authorities and gangs. From Haiti to Iran, journalists have faced being barred from practising journalism, suspended from social media, assaulted by the public, attacked by police and even family members of journalists have faced reprisals.

The media market is collapsing: The biggest story in the world is devasting the news media, as collapsing economies are causing a collapse in the news business, just when we need it most. COVID-19 has been called an 'extinction event' for local news, as advertising disappears and media around the world are shuttering. Even successful national news outlets are feeling the pinch from reduced advertising revenue, such as the collapse of the German-owned Bauer Magazines New Zealand within two weeks of the start of lockdown (Krishnamurthi, 2020a). The pain at the local level, however, is extreme. Local advertising - the last thin lifeline for many local outlets - has been cut in half overnight. And it is the local new outlets which provide the most contextually important information for local communities

\section{Project journalism and Bearing Witness}

As an enabler of postgraduate project journalism over the past 14 years in the Asia-Pacific region, as exemplified in the Pacific Journalism Review's Frontline section (Bacon 2011, 2012; Nash, 2014; Mason, 2014), the Pacific Media Centre developed a plan in 2016 for an annual two-week intensive climate change field trip for two postgraduate student/graduate journalists to gain firsthand experience of reporting on climate change issues in Fiji (Robie \& Chand, 2017; Robie, 2018; Robie \& Marbrook, 2020). This was conducted within the framework of a postgraduate International Journalism Project course. Fiji was selected as the 


\section{Figure 1: Strategic COVID journalism}

The Internews approach to addressing COVID-19 is deeply rooted in our new strategy, which calls for building the five elements of a healthy information environment. These are:

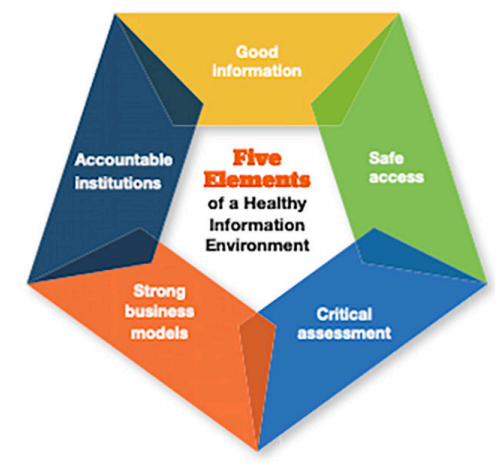

1. Good, accurate, evidence-based information;

2. That everyone can access safely;

3. That consumers know how to critically assess;

4. That is valued by communities and sustained by business models that work; and

5. Where governments and businesses are accountable for keeping it that way.

Source: Internews' Strategic Approach to COVID-19

base for the climate project for logistical and media resource reasons, given that the centre already had a long-established relationship with the USP regional Pacific journalism programme with available accommodation on the Laucala Bay campus close to the university's centre for environmental research. Also, USP is currently engaged in a major Pacific-wide climate change baseline media research project (Hutt, 2017; Singh, 2017) and there was a synergy between these two initiatives.

Another partner at USP was the Pacific Centre for Environment and Sustainable Development (PaCE-SD), which was established as a centre of excellence in 1999 for 'environmental education, research and community engagement' in the Pacific region (About us, n.d.). The director, Professor Elisabeth Holland, has led the centre in carrying out environmental and climate change research to 'empower [Pacific] people with the adequate knowledge to be able to adapt to the impacts of climate change and to also pursue sustainable development' (Holland, 2020, Robie, 2017).

The PMC project adopted the name 'Bearing Witness', drawing on the Quaker tradition of taking action over 'truth' based on conscience and being present at the sites of injustice. This seemed highly appropriate given that the field trip was seeking to provide an alternative framing of climate change journalism in terms or resilience and human rights. An inspiring example of this 'bearing witness' frame for climate change media action is the Collectif Argos (2010) photojournalism portfolio on climate refugees; many of the images were portrayed in their book with the same title. As Robie and Marbrook (2020, p. 5) outlined the evolution of the project, the aim was to 'expand the possibilities of the story itself but also the creative approaches to the way the story is told'. 
This witness project has continued for three years in the region. However, in 2020 it was replaced by the Pacific Media Watch Coronavirus Plus Project in March until May, and followed by an Internews Earth Journalism Network (EJN) Climate and Covid-19 Pacific Project between June and December, which built on the earlier PMW project. Pacific Media Watch is an independent Pacific media freedom monitor founded at the University of Papua New Guinea in 1996 and now coordinated and organised by the Pacific Media Centre in association with the Paris-based Reporters Without Borders watchdog. It has developed a strategy to "challenge issues of ethics, media freedom, industry ownership, cross-cultural diversity and media plurality' (Robie, 2014a, p. 221). It has been involved in reporting coups d'etat, civil conflict, social justice and media independence. The service has been an important catalyst for postgraduate student journalists, media educators, citizen journalists and critical journalists 'collaborating in a broader trajectory of Pacific protest' (Craddock, 2013).

The project is guided by the principles of 'reflective practice', a process whereby journalists (including student journalists), as media practitioners, continually engage in finding better and more constructive ways to inform their audience. Essentially, this means taking time off their daily deadline work to 'reflect on their practice, recapture their experience at the coalface of investigative reporting', and strategise for better ways to engage with the audience. According to Loo (2013), the reflective process involves:

1. Self-evaluation of the journalists' motivation and attitude towards their profession;

2. Reflecting on their 'professional' journalistic values in cross-cultural contexts;

3. Developing awareness of their journalistic functions in their respective society;

4. Challenging the journalists' dominant news values with alternative criteria; and

5. Applying media concepts and principles to economic, political and social realities. (Loo, 2013, p. 95-96)

The reflective process is also a strong feature of talanoa journalism, a model that seeks to integrate the 'custom' factor into media with the Pacific tradition of holistic debate as argued in papers by Robie (2013, 2014b, p. 333, 2019; Robie and Marbrook, 2020). The talanoa model makes the case for a more grassruts approach to sources and emphasises community empowerment and community ethics with recognition of Indigenous, diversity and kastom values.

\section{The Coronavirus-Plus Project and discussion}

While the Pacific Media Centre did not embark on a project with the Internews' Asia-Pacific affiliate, Earth Journalism Network, until June 2020, the Internews 


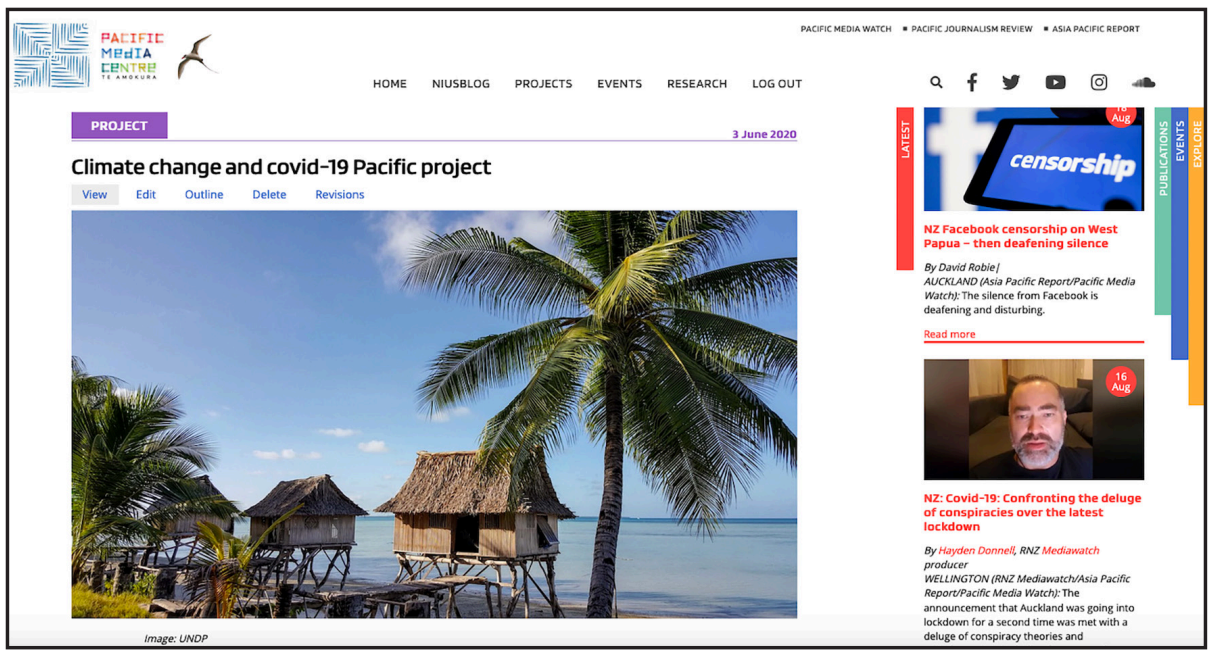

Figure 2: The Climate Change and Covid-19 Project after New Zealand's Lockdown 1.0.

Source: Pacific Media Centre

guidelines had already been adopted for the earlier 10-week project under the Pacific Media Watch umbrella (Robie, 2020b-between March 19 and May 31.) During that period, the project published 268 articles (65 in March, 120 in April and 80 in May) about the coronavirus involving analysis, news, health, science, media, political and social issues on the centre's news website Asia Pacific Report and in the centre's weekly Southern Cross radio programme broadcast in partnership with Radio 95bFM at the neighbouring University of Auckland.

The editorial team comprised part-time Pacific Media Watch contributing editor Sri Krishnamurthi, an experienced news agency journalist who had graduated with a Postgraduate Diploma in Communication Studies (Digital Media) in 2019 and was preparing for doctoral studies; PMW convenor Professor David Robie (who is also director of the PMC); supported by collaborations with RNZ Pacific, the University of the South Pacific journalism programme in Fiji, the University of Santo Tomas in the Philippines, and a network of independent journalists and academics. The core team worked from home offices under restrictions due to vulnerable age and compromised immune system categories. For communications, they used a MS Teams set up for the project along with Zoom, Skype and FB messenger video and chat feeds for interviews around the Pacific. Their portfolio (which is continuing publication) is available at: https:// asiapacificreport.nz/category/health-and-fitness/coronavirus. The following questions were put to Sri Krishnamurthi, who was the primary journalist for both phase one (Coronavirus-Plus) and phase two (EJN) of the project and who had been recruited by the Pacific Media Watch project at AUT three weeks prior to the April lockdown and was still 'settling in' when New Zealand closed its borders. 


\section{What was your role in this new Aotearoa New Zealand and Pacific mediascape} amid a global pandemic?

SK: The project was put together just before New Zealand's COVID emergency Lockdown 1.0 began and it needed to be done in order to accurately inform the public. Both David Robie and I undertook the task when we understood the enormous gravity of the situation. As both of us have had experience of working in challenging and often distressing moments in history, we knew what we had to do. My role changed from instead of just simply being a reporter; I had to also rely on the skills I had learnt as an agency reporter [for the national news agency NZ Press Association, which closed in 2011 (Stone, 2011)] — speed and use of quick and critical thinking were essential tools that were applied. With our Southern Cross radio programme, we did that remotely using Cleanfeed [a multitracked, multiparty, browser-based audio recording software] and filed for $P M W$ as many other journalists world-wide were doing in the digital age with multimedia packages. Again the expectation was for accuracy and timeliness at a moment when social media was awash with misinformation amid the 'disinfodemic'. It was incumbent on $P M W$ to disseminate only the truth. The prioritisation of this changed from covering a limited number of academic or 'soft' and background articles to hard news coverage of the pandemic and stories relating to the Pacific health crises, and failures of Pacific economies - the impacts of this and what various governments were doing in an attempt to both control the pandemic and to also seize the opportunity to gain more control of their people.

\section{What was Pacific Media Watch's objective and what were your expectations} for this challenge?

SK: Working from home brought its own problems, but nevertheless being a journalist I saw it as our duty to keep up with the Pacific Media Watch's objectives of providing accurate information to the Pacific. The problems I speak of were technological, psychological, and social—at times my technology didn't work, due to not knowing how to use some parts of it. Psychologically I found time-keeping difficult, often due to not having the motivation of working in the office and socially I often felt isolated. But for the work at hand that needed to be done, I quite easily could have fallen apart. Such are the vagaries of not having experienced a lockdown before. Each of my colleagues had various issues to deal with. I interviewed a number of Pacific journalists in New Zealandsome who had children who continuously disturbed them while they were trying to work, others worked on alternate days. One in particular [Television New Zealand's Pacific correspondent Barbara Dreaver] went out in full PPE gear and maintained a 2 metre distance while fearing she might catch the virus. Another journalist, a single man, got very bored when he wasn't working on the alternate day. 
3. Given that this was a university journalism initiative with limited resources, what was the difference with other news media covering the lockdown crisis? SK: I saw the Pacific Media Watch as a challenge. This required a new way of working and being innovative to keep the Pacific, the university and subscribers informed, unlike with the misinformation that proliferated on social media. We had to beat that and we did. It required being innovative with how we reached our colleagues in the Pacific and posing them a set of questions via email, using Facebook messenger, or if all failed ringing them and recording their answers, I found I also had to be very mindful of the questions I posed them for fear of getting our contacts in trouble with their authorities.

4. At the time of the lockdown being declared on March 19, the World Health Organisation (WHO) was already warning about the dangers of a 'disinfodemic' and an avalanche of 'fake news' and medical misinformation. How did you and PMW deal with this?

SK: It required a lot of new responsibilities and we managed this with a team of just two people, compared with the major media companies with large teams of journalists. I felt very proud to have worked on this project and we managed it very well. Large media companies have a lot more resources but the disappointing aspect was that they were only concentrating on New Zealand and that

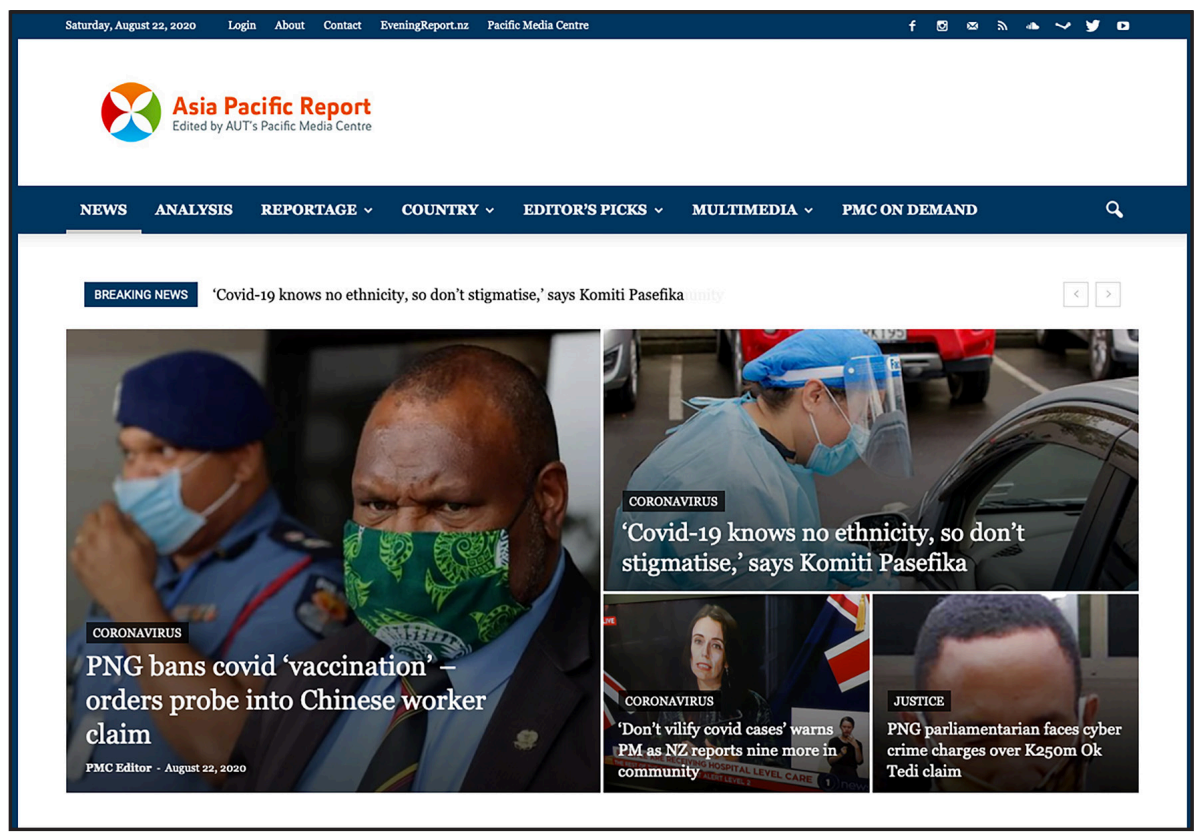

Figure 3: Face masks, bans, cyber crime and vilification ... all in a day's news on Asia Pacific Report.

190 PACIFIC JOURNALISM REVIEW 26 (2) 2020 
insularity meant they largely ignored their Pacific neighbours. That insularity doesn't bode well for the Pacific in the future.

5. You also contributed a regular Pacific Pandemic Diary, what were the highlights of this Lockdown 1.0 period for you?

SK: We sourced accurate information from a multitude of sources like our $\mathrm{Pa}$ cific Media Watch wires; Radio New Zealand; from a number of correspondents around the Pacific, such as Scott Quade in Papua New Guinea; FBC News in Fiji and the student journalists of Wansolwara [University of the South Pacific journalism programme's student journalism newspaper]; Barbara Dreaver at TVNZ; and by following up our contacts such as Australian-based correspondents and analysts, including Dr Tess Newton-Cain, Sue Ahearn [retired former head of news at the ABC] as well as [former media director at the Vanuatu Daily Post] Dan McGarry and [photojournalist] Ben Bohane, who are based in Vanuatu.

\section{What were the some of the highlights of this Lockdown 1.0 period for you?}

SK: Highlights of the Pacific Pandemic Diary were the slow authoritarian creep right across the Pacific from governments that used COVID-19 as a reason/ excuse for applying draconian rules which to mind was first recognised and written about by David Robie (2020), in one of his contributions to the Diary. Recognising this, I also wrote a follow-up on governments around the Pacific using COVID-19 to put in laws that impinged on democratic rights. I was also pleasantly surprised by the resurgence of birdlife in Auckland city and wrote an article about that (see Krishnamurthi, 2020b, and Part 2) as well as lauding the decision made by Prime Minister Jacinda Ardern to 'go hard, go early' for the team of five million.

7. Since then, you have been involved in the PMC's new challenge, the EJN [Internews] Climate and Covid-19 Pacific Project that began in June. How do you see where the priorities may have changed?

SK: The priorities have definitely changed. People, rightfully, are concerned primarily about COVID as seen by the work and worries expressed by photojournalists right across the Pacific in a 12-week course held by Vanuatu-based photographer and videographer Ben Bohane (VII Pacific, 2020). Their diversity of work has been impressive, such as portraying people wearing masks or being temperature tested, a young woman washing her hands outside from a plastic drum of water, wondering what the photojournalist was doing, the flag system used on lamp posts to tell what territory you were travelling through with 'red' being COVID-19 as vehicles moved through, or a particularly poignant one of a photographer cutting the umbilical cord of his new-born child ... all during the time of COVID. But that is not to say climate change has disappeared 
from people's minds. It might have taken a backseat for the moment but the reality of how COVID has slowed climate change initiatives in the Pacific is apparent (Krishnamurthi, 2020c). Nonetheless, the $P M W$ project — and the EJN Climate and Covid Project that follows highlight this importance because of the threat it poses to the Pacific,

8. Now that New Zealand is in the middle of Lockdown 2.0 (in Auckland at the time of writing) in the lead-up to the General Election on October 17, press gallery journalists are being increasingly criticised for 'lack of solidarity' with the Ardern government's public health priorities and strategy for New Zealand. Any reflections about this?

SK: At times, there were media commentators like conservative NewstalkZB broadcaster Mike Hosking [Government has overcooked the lockdown, 2020] who were calling for an easing of lockdowns, and then saying [the government] should be harder, so you did get a feeling he was neither here nor there. As for the press gallery, by the very nature of being there journalists are privileged and conflict is the name of the game, as is [challenging] the standing government. The beltway plays by its own rules and hence people didn't always get the feeling that they understood what the Prime Minister and the Director-General of Health, Dr Ashley Bloomfield, were trying to do. Instead they sought holes in their strategy - some of it justified, like over the distribution of PPE equipment-but repeatedly asking the same questions and lack of understanding showed up the gallery journalists as being very hollow.

9. What did the PMW achieve or contribute from your perspective as contributing editor given that you had made a short documentary about the project last year when you interviewed former editors and journalists (Krishnamurthi, 2019)?

SK: It gained an enormous international profile and was excellent in terms of working with a team of two, using technology to stay in touch. I believe the $P M W$ project earned even more exposure than it already had as a highly respected website of accurate information keeping the Pacific, in particular, well informed. As contributing editor I felt it was a privilege to work alongside David through some very difficult days during the pandemic. And the fact that we kept the $P M W$ going when other news media around us, such as Bauer (Krishnamurthi, 2020b), were failing showed a tenacity that was unique and a true commitment to providing the Pacific with a rare quality of information.

\section{Your final reflection?}

SK: The value of Pacific Media Watch and its benefit for university students who do an internship with the project simply cannot be underestimated. The value of the PMW is clearly illustrated in the documentary Pacific Media Watch-The 
genesis (Krishnamurthi, 2019) that covers the military coups in Fiji, the heinous treatment of the people of West Papua and media freedom issues in the Pacific, as do also the Bearing Witness and EJN projects on climate change and COVID. They are vital to be continued.

\title{
Conclusion
}

The Pacific Media Centre adapted early in its response to the COVID-19 coronavirus pandemic. Recognising the rapidly expanding global nature of the crisis, the centre laid the groundwork and prepared to embark on its Coronavirus Plus Project in early March, more than two weeks before New Zealand went into its first national lockdown on March 25, including the closure of university campuses. The PMC deployed its Pacific Media Watch Coronavirus Plus project with the small team working from home and using various sharing software programmes to communicate and to continue publishing on Asia Pacific Report.

It was critically important to provide basic information on how to survive and persevere during this pandemic and to counter the 'disinfodemic'. Using a long established network of media partnerships and collaborations along with contributing student journalists from Aotearoa New Zealand, Fiji and the Philippines, the project was able to establish a credible and innovative news coverage. Eventually early fears in New Zealand that foreign political consultants and fringe parties would turn Facebook followers and fake news into votes in the October general election as in Australia, France, United Kingdom, and the United States proved unfounded. As RNZ Mediawatch concluded, 'the major parties mostly ran a clean game online too' (Peacock, 2020).

\begin{abstract}
[Musician] Billy Te Kahika Jr seized on COVID-19 [foreign-fed] misinformation and conspiracy theories in his bid to build support for his new political movement - later joined by former Botany MP Jami-Lee Ross and his Advance NZ party. Just two days from the end of polling Facebook removed Advance NZ's page for 'repeated' violations of its misinformation policy. (Molyneaux, 2020)
\end{abstract}

However, researchers have warned that while the 'disinformation' party had only converted a fraction of their Facebook following, more social media influence could be expected in future elections (Election 2020, 2020). With such a complex information mediascape where the pervasive and relentless nature of the COVID-19 virus severely hampered face-to-face interaction, Internews (2020) among other agencies argued that it was important for local media to 'communicate with communities, providing timely, accurate and trustworthy information'. The Pacific Media Centre and Asia Pacific Report capitalised on its deep media connections in the Asia-Pacific region to offer a unique and valuable service. 
It is likely that global communities will face the COVID pandemic for many months, perhaps years, to come. The reflexive project journalism model deployed by the Pacific Media Centre is well placed for a group of enterprising postgraduate students to develop information and media solutions. This model is especially effective for coping with long-term development and humanitarian challenges linked to critical issues such as climate change, environmental disasters, natural disasters and public health epidemics.

\section{Resources}

Coronavirus Plus project on Southern Cross radio at 95bFM:https://soundcloud.com/ user-688507213

Pacific Media Watch Coronavirus Plus project on Asia Pacific Report:https://asiapa cificreport.nz/category/health-and-fitness/coronavirus/

EJN Climate and Covid Pacific project on Asia Pacific Report: https://asiapacificreport. $\mathrm{nz} /$ category/climate/climate-covid-project/

\section{References}

About us (n.d.). Pacific Centre for Environment and Sustainable Development (PaCESD). Retrieved September 3, 2020, from https://pace.usp.ac.fj/

Bacon, W. (2011). Investigative journalism in the academy - possibilities for storytelling across time and space. Pacific Journalism Review : Te Koakoa, 17(1), 45-66. https:// doi.org/10.24135/pjr.v17i1.371

Bacon, W. (2012). FRONTLINE: An innovative direction in academic journalism. Pacific Journalism Review : Te Koakoa, 18(2), 153-165. https://doi.org/10.24135/pjr. v18i2.270

Banbury, J. (2020, August 20). Why is National struggling to convince voters? Democracy Project. Victoria University of Wellington. Retrieved August 21, 2020, from

Bradbury, M. (2020, October 22). The 2 simple reasons why Labour won an unprecedented MMP majority. The Daily Blog. Retrieved October 25, 2020, from https:// thedailyblog.co.nz/2020/10/22/the-2-simple-reasons-why-labour-won-an-unprecedented-mmp-majority/

Collectif Argos. (2010). Climate refugees. Introductions by Hubert Reeves and Jean Jouzel. Boston: Massachusetts Institute of Technology.

Cooper, A. (2020, April 13). How COVID-19 is threatening press freedom: An interview with Joel Simon. Journalist's Resource. Retrieved August 9, 2020, from https:// journalistsresource.org/studies/society/news-media/coronavirus-covid-19-pressfreedom-joel-simon/

Coronavirus: Outcry after Trump suggests injecting disinfectant as treatment (2020, April 24). BBC News. Retrieved August 18, 2020, from https://www.bbc.com/news/ world-us-canada-52407177

Cousins, S. (2020, May 9). New Zealand eliminates COVID-19. The Lancet, 395(10235), 1474. doi: https://doi.org/10.1016/S0140-6736(20)31097-7

COVID-19: Elimination strategy for Aotearoa New Zealand (2020, May 8). Ministry of Health Manatu Hauora. Retrieved August 18, 2020, from https://www.health.govt. nz/our-work/diseases-and-conditions/covid-19-novel-coronavirus/covid-19-currentsituation/covid-19-elimination-strategy-aotearoa-new-zealand

Craddock, P. (2013). Pacific journalists and frontline freedom. [Review]. Pacific Journalism Review : Te Koakoa, 19(1), 299-302. https://doi.org/10.24135/pjr.v19i1.254 
During this coronavirus pandemic, 'fake news' is putting lives at risk: UNESCO (2020, April 13). UN News. Retrieved on August 18, 2020, from https://news.un.org/en/ story/2020/04/1061592

Election 2020: Key social media trends (2020, n.d.). Dr Mona Krewel \& Professor Jack Vowles: negative campaigning, fake news, and half-truths among the minor parties: And the question: Is Advance New Zealand really 'populist'. Retrieved October 25, 2020, from https://www.wgtn.ac.nz/research/strengths/election

Forrester, G. (2020, May 5). Coronavirus: Jacinda Ardern praised for 'master class' response to covid-19 crisis. Stuff. Retrieved August 18, 2020, from https://www.stuff. co.nz/national/health/coronavirus/121405409/coronavirus-jacinda-ardern-praisedfor-master-class-response-to-covid19-crisis

Holland, E. (2020). Tropical Cyclone Harold meets the novel coronavirus: Dispatch from the Pacific. Pacific Journalism Review: Te Koakoa, 26(1), 243-251. https://doi. org/10.24135/pjr.v26i1.1099

Hopgood, S. J. (2020, August 23). Pacific community come out in force during NZ's covid-19 testing. RNZ Pacific/Asia Pacific Report. Retrieved August 23, 2020, from https://asiapacificreport.nz/2020/08/23/pacific-community-come-out-in-force-duringnzs-covid-19-testing/

Hutt, K. (2017, May 18). Pacific-wide study aims to understand how journalists cover climate change. Pacific Media Watch Fiji \#9982. Retrieved September 3, 2020, from https://pmc.aut.ac.nz/pacific-media-watch/fiji-pacific-wide-study-aims-understandhow-journalists-cover-climate-change

Internews' Strategic Approach to COVID-19: Information Saves Lives (2020, April). Internews. Retrieved August 22, 2020, from https://internews.org/sites/default/ files/2020-05/Internews_Strategic_Approach_COVID19_April2020.pdf

Johnson, G. (2020a, July 8). How New Zealand's media endangered public health. Al Jazeera English. Retrieved August 18, 2020, from https://www.aljazeera.com/indepth/ opinion/zealand-media-endangered-public-health-200707103532946.html

Johnson, G. (2020b, August 21). Coronavirus and conspiratorial dog-whistles return to New Zealand. Al Jazeera English. Retrieved August 22, 2020, from https://www. aljazeera.com/indepth/opinion/coronavirus-conspiratorial-dog-whistles-returnzealand-200820113656292.html

Krishnamurthi, S. (2019, July 10). Pacific Media Watch-The genesis. [Video]. Pacific Media Centre. Available at: https://www.youtube.com/watch?v=xvd-iwd7LZA

Krishnamurthi, S. (2020a, April 3). Media suffer 'devastating' blows on both sides of the Tasman. Asia Pacific Report. Retrieved August 18, 2020, from https://asiapacificreport.nz/2020/04/03/trans-tasman-media-suffers-a-blow-on-both-sides-on-the-tasman

Krishnamurthi, S. (2020b, April 20). 'Stop, listen, Papatūānuku, the earth mother, is breathing'. Asia Pacific Report. Retrieved September 3, 2020, from https://asiapacificreport.nz/2020/04/20/stop-listen-papatuanuku-the-earth-mother-is-breathing/

Krishnamurthi, S. (2020c, September 21). How COVID priorities have shelved 'PNG' climate change action. Asia Pacific Report. Retrieved September 20, 2020, from https://asiapacificreport.nz/2020/09/21/how-covid-priorities-have-shelved-pngclimate-change-action/

Krishnamurthi, S. (2020d, October 22). How Pacific environmental defenders are coping with the Covid-19 pandemic. Earth Journalism Net. Retrieved on October 25, 2020, from https://earthjournalism.net/stories/how-pacific-environmental-defenders-are-copingwith-the-covid-19-pandemic

Loo, E. (2013). Training journalists in context. In Bridging the cultural gaps in journalism 
training and education in Asia (pp. 91-109).

Mason, B. (2014). FRONTLINE: Journalism practice and critical reflexivity: A death in custody interview. Pacific Journalism Review : Te Koakoa, 20(1), 158-179. https:// doi.org/10.24135/pjr.v20i1.192

Media Programme Asia. Singapore: Konrad Adenauer Stiftung.

Mike Hosking: Government has overcooked the lockdown (2020, April 21). The New Zealand Herald. Retrieved September 3, 2020, from https://www.nzherald.co.nz/nz/ news/article.cfm?c id=1\&objectid $=12326281$

Molyneux, V. (2020, Ōctober 15). Facebook removes Advance NZ page for 'repeated' misinformation about COVID-19. Newshub. Retrieved October 25, 2020, from https://www.newshub.co.nz/home/politics/2020/10/facebook-removes-advance-nzpage-for-repeated-misinformation-about-covid-19.html

Nash, C. (2014). Research degrees in journalism: What is an exegesis?. Pacific Journalism Review : Te Koakoa, 20(1), 76-98. https://doi.org/10.24135/pjr.v20i1.188

Nash, C. (2016). What is journalism: The art and politics of a rupture. London: Palgrave Macmillan.

Nolan, J. (2020, June 18). Will Timor-Leste be the region's latest press freedom casualty? The Interpreter. Retrieved August 18, 2020, from https:/www.lowyinstitute.org/theinterpreter/will-timor-leste-be-region-s-latest-press-freedom-casualty

Peacock, C. (2020, October 25). Should we fear fake news in our politics? RNZ Mediawatch. Retrieved October 25, 2020, from https:/www.rnz.co.nz/national/programmes/ mediawatch/audio/2018769801/should-we-fear-fake-news-in-our-politics

Posetti, J., \& Bontcheva, K. (2020). Disinfodemic: Dissecting responses to covid-19 disinformation: Policy brief 2. United Nations Educational, Scientific and Cultural Organisation. Retrieved August 18, 2020, from https://en.unesco.org/sites/default/ files/disinfodemic_dissecting_responses_covid19_disinformation.pdf

Robie, D. (2013). The 'talanoa' and the tribal paradigm: Reflections on cross-cultural reporting in the Pacific. Australian Journalism Review, 35(1), 43-58.

Robie, D. (2014a). Pacific Media Watch: Beyond parochial news, Media Asia, 41(3), 220-226. doi: 10.1080/01296612.2014.11690019

Robie, D. (2014b). Don't spoil my beautiful face: media, mayhem and human rights in the Pacific. Auckland: Little Island Press.

Robie, D. (2018). Bearing Witness 2017: Year 2 of a Pacific climate change storytelling project. Pacific Journalism Review : Te Koakoa, 24(1), 155-177. https://doi. org/10.24135/pjr.v24i1.415

Robie, D. (2019). Karoronga, kele'a, talanoa, tapoetethakot and va: expanding millennial notions of a 'Pacific way' journalism education and media research culture, Media Asia, 46(1-2), 1-17, doi: 10.1080/01296612.2019.1601409

Robie, D. (2020a, April 4). Creeping authoritarianism in Pacific not the answer to virus pandemic. Pacific Pandemic Diary. Asia Pacific Report. Retrieved August 18, 2020, from https://asiapacificreport.nz/2020/04/04/creeping-authoritarianism-in-pacificnot-the-answer-to-virus-pandemic/

Robie, D. (2020b). 'Stay home, stay safe, be kind': How New Zealand crushed, not just flattened the COVID curve. In K. Seneviratne \& S. Muppidi (Eds.), Racism and politicisation: Media in the midst of a pandemic. Springer (Forthcoming).

Robie, D., \& Chand, S. (2017). Bearing Witness 2016: A Fiji climate change journalism case study. Pacific Journalism Review : Te Koakoa, 23(1), 186-205. https://doi. org/10.24135/pjr.v23i1.257

Robie, D., \& Marbrook, J. (2020). Bearing Witness: A Pacific climate crisis documentary 
and journalism development project. Asia Pacific Media Educator. Published online 15 September 2020. https://doi.org/10.1177/1326365X20945417

RSF (Reporters Without Borders) (2020a). 2020 World press freedom index: 'Entering a decisive decade for journalism, exacerbated by coronavirus'. Retrieved August 18, 2020, from https://rsf.org/en/2020-world-press-freedom-index-entering-decisivedecade-journalism-exacerbated-coronavirus

RSF (Reporters Without Borders) (2020b, June 15). Coronavirus 'information heroes' journalism that saves lives. Retrieved August 18, 2020, from https://rsf.org/en/news/ coronavirus-information-heroes-journalism-saves-lives

Singh, S. (2017, November 7). A core challenge with reporting climate change is sustaining public interest. Stuff. Retrieved September 3, 2020, from https://www.stuff. co.nz/tarana/98608482/a-core-challenge-with-reporting-climate-change-is-sustainingpublic-interest

Stone, A. (2011, August 31). Farewell NZPA, hello three new services. The New Zealand Herald. Retrieved August 9, 2020, from https:/www.nzherald.co.nz/business/news/ article.cfm?c id=3\&objectid $=10748448$

UN launches new initiative to fight COVID-19 misinformation (2020, May 21). UN News. Retrieved August 12, 2020, from https://news.un.org/en/story/2020/05/1064622

UN tackles 'infodemic'of misinformation and cybercrime in COVID-19 crisis (2020, March 31). United Nations Department of Global Information. Retrieved August 18, 2020, from https://www.un.org/en/un-coronavirus-communications-team/un-tackling$\%$ E2\%80\%98infodemic $\%$ E2\%80\%99-misinformation-and-cybercrime-covid-19

UNESCO battles COVID-19 'disinfodemic' (2020, April 13). Arête News. Retrieved August 18, 2020, from https://aretenews.com/unesco-battles-covid-19-disinfodemic/

Universal Declaration of Human Rights (1948). Article 19: Freedom of expression. United Nations Charter.

VII Pacific (2020). Photojournalism and documentary photograohy: A VII Academy 12-week seminar with Ben Bohane for Pacific region participants, 3 July 2020-18 September 2020. Retrieved September 2, 2020, from https://vii.academy/events/ photojournalism-and-documentary-photography-a-vii-academy-12-week-seminarwith-ben-bohane-for-the-pacific-region-participants/

WHO Novel Coronavirus (2019-nCoV) Situation Report 13 (2020, February 2). World Health Organisation (WHO). Retrieved August 18, 2020, from https://www.who. int/docs/default-source/coronaviruse/situation-reports/20200202-sitrep-13-ncov-v3. pdf?sfvrsn=195f4010_6

Dr David Robie is a Pacific journalism professor and director of the Pacific Media Centre at Auckland University of Technology. He is the founding editor of Pacific Journalism Review and the author of several books on AsiaPacific news media and political economy. Sri Krishnamurthi is contributing editor of the Pacific Media Centre's Pacific Media Watch freedom project. An earlier version of this article was originally presented as a paper at the Symposium on Social Science 2020: Rethinking the Social World in the 21st Century at Yogyakarta, Indonesia, in webinar format on 24-25 August 2010. 


\section{Part 2: PANDEMIC DIARY CORONAVIRUS UPDATES - DAY 26}

https://asiapacificreport.nz/2020/04/20/stop-listen-papatuanuku-the-earth-motheris-breathing/

\section{'Stop, listen, Papatūānuku, the earth mother, is breathing'}

By Sri Krishnamurthi , 20 April 2020

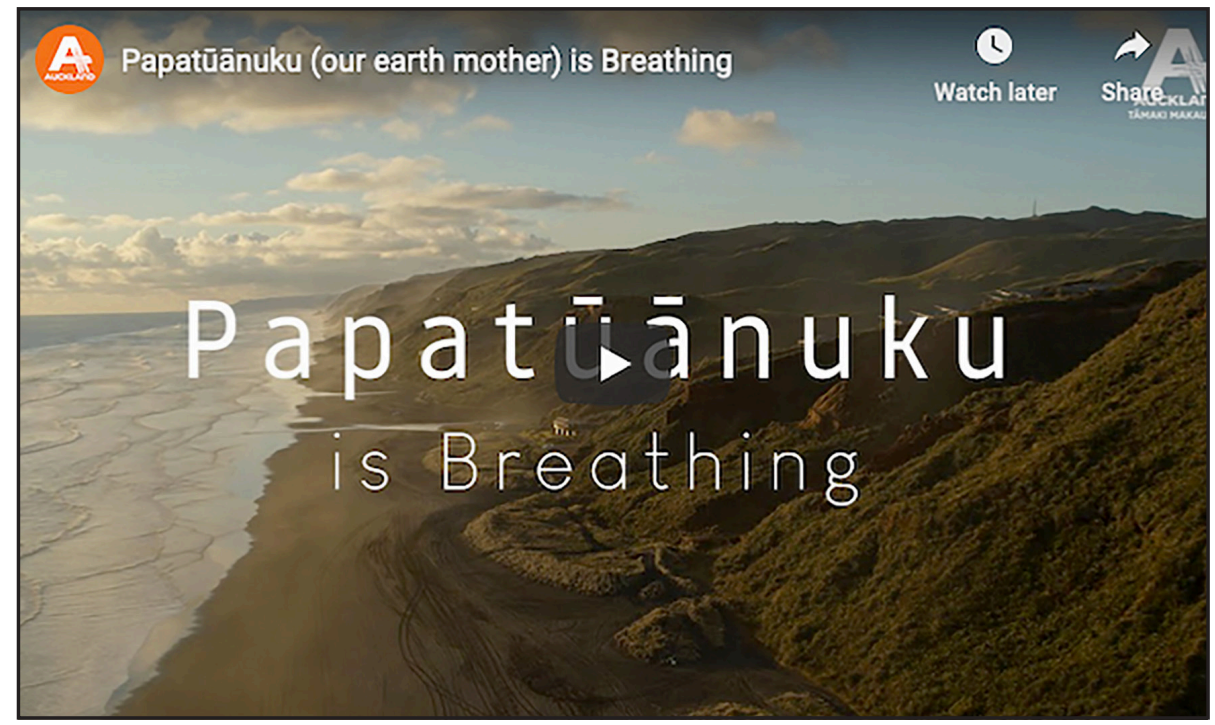

Figure 5: The Papatūānuku is Breathing video.

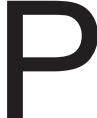

apatūānuku - earth mother is breathing,

The mere suggestion that you can see and hear tūī and kererū in Auckland was once a myth... but no longer as COVID-19 keeps the traffic at bay.

Even in Auckland you can now hear birds as clear as daylight as the air clears over New Zealand's biggest city, reputed to be the largest Polynesian city in the world.

The tūi, with a distinctive white throat tuft, is usually very vocal, with a complicated mix of tuneful notes interspersed with coughs, grunts, and wheezes. In flight, their bodies slant with the head higher than the tail, and their noisy whirring flight is interspersed with short glides.

And the kererū, or wood pigeon, is a large bird with iridescent green and bronze feathers on its head and a smart white vest. The noisy beat of its wings is a distinctive sound in our forest.

You don't hear them normally in urban New Zealand, but the air has been 
so clean that they are back, and many people have commented on hearing the birds chirping in their gardens.

That is because our earth mother, Papatūānuku, is breathing.

\section{Celebrating silence}

A video that celebrates the silence of our biggest city in the Covid-19 lockdown has become the biggest ever global hit on the Visit Auckland YouTube channel $-218,940$ view at last count.

Papatūānuku is breathing, narrated by 11-year-old Manawanui Maniapoto Mills, pans across Auckland's natural landscapes as human activity almost stops during the lockdown.

"Stop, listen, Papatūānuku, the earth mother, is breathing, Tāmaki Makaurau Auckland is still," it begins.

"Out tūī, our kererū, now need not fight with the daily hum of our busy lifestyles."

And at the end: "Dream, plan, and when the time is right, we welcome you, but for now listen, Papatūānuku is breathing."

Auckland Tourism, Events and Economic Development (Ateed) destination general manager Steve Armitage says the video's message was "designed to be simple: this is a time of rest; take a moment to appreciate the stillness and the beauty of our region".

"We hope the video is encouraging for Kiwis entering their third week of lockdown," he added.

Within just days of its release on social media, the video has amassed more than half a million views and generated the most engagement for ATEED.

It has been viewed by not only New Zealanders, but by people in Australia, the United States, United Kingdom, and Canada.

\section{Translated into French, Spanish}

It has even been translated into French and Spanish by "inspired viewers".

It is a haunting video that shows the best of New Zealand.

More than 40,000 Pacific people in New Zealand have benefitted from the government's COVID-19 support packages.

The Pasifika Medical Association through Pasifika Futures- the Whanau Ora commissioning agency for Pacific families - said nearly 7500 packages had been delivered to families since the lockdown was announced on March 23.

Data to determine if community transmission of COVID-19 is occurring in New Zealand will be a big factor in tomorrow's decision on whether to extend the level 4 lockdown, reports RNZ News.

At a media briefing, Director-General of Health DrAshley Bloomfield reported nine new cases of COVID-19 in New Zealand. All were linked to existing cases.

There were now 18 people in hospital, including three in intensive care, with two in a critical condition and 1098 cases, while more than 4000 tests were processed in laboratories yesterday. Dr Bloomfield also confirmed a death that occurred in Invercargill last week was a Covid-19-related death, taking the total to 12 . 


\section{7 cases in $\mathrm{Fiji}$}

Fiji going into the weekend had 17 cases. A 21-year-old who had been a travelling companion of a man who visited India to go to a religious festival who flagrantly disregarded all self-isolation rules has now infected several people.

Also going into the weekend, Papua New Guinea, which is ill-prepared for the Covid-19 pandemic, had prime minster James Marape confirm they had five new cases taking the total to seven.

Guam had 135 cases and five deaths going into the weekend and the sailors off the USS Theodore Roosevelt had 615 positive cases.

Northern Marianas has 13 cases and two deaths, Tahiti has 55 cases and New Caledonia is still at 18.

In all going into the weekend there were 250 cases in the Pacific with seven deaths around the Pacific.

Meanwhile, Reporters without Borders (RSF) is alarmed to learn that Indonesia's police have been ordered to combat not only disinformation about the coronavirus pandemic but also criticism of the president and government.

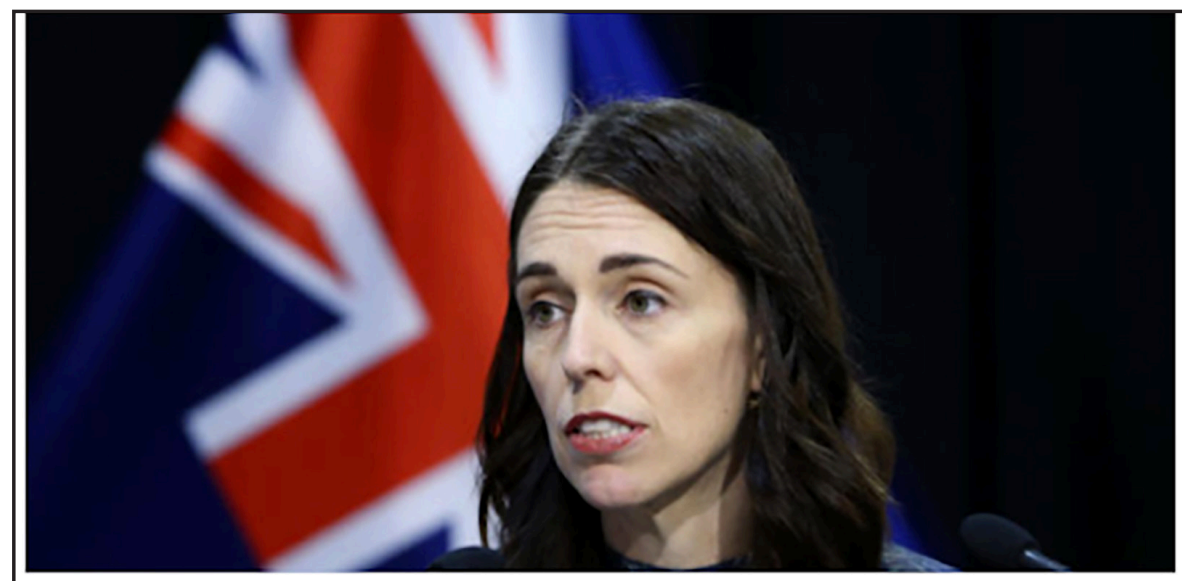

\section{NZ lockdown - day 25: Nine new cases - community spread key to lockdown}

By RNZ News Data to determine if community transmission of Covid-19 is occurring in New Zealand will be a big factor in tomorrow's decision on whether to extend the level 4 lockdown. At a media briefing this afternoon, Director-General of Healt $\mathrm{h} \mathrm{Dr}$ Ashley Bloomfield reported nine new cases of Covid-19 in New Zealand. All ... Continue reading

Asia Pacific Report

Figure 5: A snapshot of an Asia Pacific Report COVID community transmission update. 